\title{
CENTRALISATION OF HALAL MATTERS UNDER THE FEDERAL GOVERNMENT IN MALAYSIA: A LEGAL PERSPECTIVE
}

\author{
Apnizan Abdullah* \\ Mohamed Azam Mohamed Adil**
}

\begin{abstract}
Generally, halal matters in Malaysia are governed by piece-meal legislation, inter alia, the Trade Descriptions Act (TDA) 2011 and its by-laws, the Food Act 1983, Food Regulations 1985, state-issued fatwas, and the rules and guidelines promulgated by relevant authorities, whether under the federal or state governments. Consequently, as prescribed by the law, halal matters are assigned to various different entities. For instance, the Ministry of Domestic Trades, Cooperatives and Consumerism (KPDNHEP) supervises halal trade practices. Both the Department of Islamic Development Malaysia (JAKIM) and Islamic Religious Councils (IRCs) of the states take charge of the halal certification portfolio. The Halal Industry Development Corporation (HDC) handles services related to the internationalisation of halal products, whereas the Department of Standards Malaysia (DOSM) issues and revises time-relevant halal standards. This situation, however, may lead to the overlapping of mandates and confusion among industry players as to whether halal matters fall under the federal or state governments as prescribed in List II of the Malaysian Federal Constitution. Since Malaysia is at the global forefront of promoting the halal agenda, the Malaysian government must call for the centralisation of its regulatory framework to provide better supervision and harmonise practices in the industry. Hence, this paper discusses and deliberates on the legal and regulatory outlook of the country for the purpose of centralising halal matters under the federal government of Malaysia.
\end{abstract}

Keywords: halal, halal certification, halal industry, halal standards, centralisation of halal, jurisdiction.

\section{Introduction}

In 2017, the value of the global halal industry was estimated at around USD2.3 trillion. It is predicted to grow at a projected annual rate of 20 per cent. ${ }^{1}$ The global halal product market is therefore expected to grow from USD45.3 billion in 2016 to over USD58.3 billion by 2022. The largest sector of the global halal industry is 
Islamic finance, with a 43 per cent market share, followed by halal food with 36 per cent. ${ }^{2}$ Halal food had a global market value of approximately USD1.4 trillion in 2017 and is expected to reach USD2.6 trillion by 2023. The leading importers of halal food in 2015 among the OIC countries were Saudi Arabia, Malaysia and the United Arab Emirates. The most popular imported food for these countries was beef. The halal industry has even enticed non-Muslim countries into taking part, as among the top exporters of halal beef are Brazil, Australia and India. Indonesia marked itself out as the OIC country with the highest expenditure on food and beverages in 2015. ${ }^{3}$ These statistics indicate a trend of increasing demand for halal products and services around the globe year-on-year, a trend which is predicted to grow parallel to the growing Muslim population. According to the Pew Research Center, the world's Muslim population is expected to increase from 1.6 billion in 2010 to 2.2 billion by 2030 , with a projected growth of 35 per cent. ${ }^{4}$ This estimation signifies considerable potential for further development in the halal industry, development that would attract many countries, be they Muslim majority countries or non-Muslim countries.

Malaysia intensified its efforts to promote halal as a national agenda under the premiership of Tun Abdullah Ahmad Badawi (2003-2009). With its position as the market leader in Islamic banking and finance, Malaysia had strong potential to play a pivotal role in further developing the halal industry globally. Badawi's footsteps were rigorously pursued by his successor, Najib Tun Razak, who included halal as part of the "Eleventh Malaysia Plan: 2016-2020". Numerous government and non-government agencies were mandated with various tasks to actualise Malaysia's aspiration to become the global halal hub; these agencies included the Halal Industry Development Corporation (HDC), Department of Islamic Development Malaysia (JAKIM), MATRADE, MITI, Ministry of Finance, SME Corporation, Department of Standards (DOSM), Economics Planning Unit (EPU), International Institute of Advanced Islamic Studies (IAIS) Malaysia, and the Ministry of Health.

Currently, the halal industry in Malaysia is governed by various laws and regulations, including the Trade Descriptions Act (TDA) 2011 and its bylaws, the Food Act 1983, Food Regulations 1985, state-issued fatwas, selected standards, and rules and guidelines tabled by the relevant authorities. Different agencies and entities have carried out their mandates accordingly. For instance, halal certification is prescribed by its governing law, namely TDA 2011, to fall within the purview of JAKIM under the federal government, and the IRCs under the state governments. This law is stated in the Trade Descriptions (Definition of Halal) Order 2011 and Trade Descriptions (Certification and Marking of Halal) Order 2011. In discharging their duty as the sole authorities for halal certification in the country, JAKIM and the IRCs require the cooperation and involvement of other bodies: For instance, the Department of Veterinary Services (DVS) of 
the Ministry of Agriculture should assist the halal certification process when it involves meat or other livestock slaughtering.

Furthermore, the provisions in the Trade Descriptions (Definition of Halal) Order 2011 and Trade Descriptions (Certification and Marking of Halal) Order 2011 imply that halal matters fall within the state's jurisdiction, since halal could be interpreted as part of Islamic law as spelt out in Item 1 of List II of the Ninth Schedule of the Malaysian Federal Constitution. The announcement by the new government in 2018 of a proposed National Halal Council Bill has indicated that the federal government will centralise halal matters in order to streamline all matters related to the halal industry. Thus, this paper deliberates on the legal outlook of halal matters in Malaysia and concludes that they could be legally centralised under the federal government.

\section{Halal Industry in Malaysia: An Overview}

According to the 'State of the Global Islamic Economy Report 2018/19', for the fifth year running Malaysia has been the leading Islamic economy ecosystem. ${ }^{5}$ In 2017, Malaysia recorded RM43.3 billion in halal exports, making up $4.6 \%$ of the nation's total exports (of RM935.4 billion). Top importers of halal products from Malaysia were Singapore (RM4.9 billion), China (RM4.9 billion), Japan (RM2.8 billion), the US (RM2.7 billion) and Indonesia (RM2.2 billion). ${ }^{6}$

Since the premiership of Tun Abdul Ahmad Badawi, efforts have been taken by the Malaysian government to pursue a halal agenda. One of the essential steps undertaken since that period is the mandating of selected entities with specified halal portfolios, as illustrated in Table 1 .

\begin{tabular}{|l|l|}
\hline Entities & Mandates \\
\hline JAKIM & Halal certification and logo \\
\hline DOSM & Halal-related standards \\
\hline HDC & $\begin{array}{l}\text { Coordination of the overall development of } \\
\text { the halal industry in Malaysia, as well as its } \\
\text { internationalisation }\end{array}$ \\
\hline $\begin{array}{l}\text { Ministry of Domestic Trades, } \\
\text { Cooperatives and Consumerism }\end{array}$ & Halal trade practices \\
\hline $\begin{array}{l}\text { Department of Veterinary } \\
\text { Services (DVS) of the Ministry } \\
\text { of Agriculture }\end{array}$ & $\begin{array}{l}\text { Halal meat and livestock industries, } \\
\text { especially the slaughtering process }\end{array}$ \\
\hline
\end{tabular}




\begin{tabular}{|l|l|}
\hline Ministry of Health & $\begin{array}{l}\text { Supervision of the certification processes } \\
\text { related to manufacturing and safety, for } \\
\text { instance the process related to Good } \\
\text { Manufacturing Practices (GMP) and Hazard } \\
\text { Analysis \& Critical Control Points (HACCP) }\end{array}$ \\
\hline
\end{tabular}

Table 1: Halal Mandates

The Halal Industry Development Corporation (HDC), for instance, was established in September 2006 to further boost the halal agenda in terms of branding enhancement, industry expansion, and internationalisation strategies. The HDC has been collaborating with other relevant agencies to promote the development of the halal industry in Malaysia, including JAKIM, MATRADE, MITI, Ministry of Finance, Ministry of Health, SME Corporation, DOSM, Economics Planning Unit (EPU), IKIM, and IAIS Malaysia. One important outcome has been the introduction of several standards concerning halal industry practice, issued by the Department of Standards Malaysia (DOSM). As of March 2019, a total of 16 standards have been issued. Currently, apart from JAKIM and the IRCs, which are handling the halal certification process, there are 12 ministries and 342 halal-related agencies involved in the industry. This position could lead to the overlapping of mandates and confusion amongst market players. ${ }^{7}$ The establishment of the Malaysia Halal Council (MHC) in 2016 marked another milestone in the Malaysian halal industry. The MHC is tasked with coordinating all previous halal-related entities, all of which have carried out various mandates related to halal matters.

Under the present government, headed by Tun Dr Mahathir, the halal agenda is still a concentrated area for economic collaboration between Malaysia and other countries. ${ }^{8}$ According to the Malaysia International Halal Showcase (MIHAS), Malaysia has undertaken a myriad of essential regulatory, trade, and industry initiatives to further develop its halal agenda. Among the latest developments are the harmonisation of the halal accreditation process by JAKIM and Malaysia's strategic partnership in the "Halal Silk Route", which is set to change the logistics landscape between Malaysia and China. ${ }^{9}$ Malaysia will expand its halal services to 10 new countries through China's USD1 trillion investment in the One Belt, One Road (OBOR) initiative. These new countries include Kazakhstan, Uzbekistan, Egypt, Turkmenistan, Iran, Tajikistan, and Bosnia and Herzegovina. ${ }^{10}$

Despite the change of government after Malaysia's $14^{\text {th }}$ general election in 2018, efforts to streamline the supervision of halal matters have continued under the current government. In 2018, Deputy Minister in the Prime Minister's 
Department (Religious Affairs), Fuziah Salleh, stated that the government would introduce a National Halal Council Act by early 2019, an initiative that has subsequently been postponed until $2020 .{ }^{11}$ This proposed act will ensure that the instructions and functions of different agencies are clear. Hence, it will serve to strengthen the implementation of halal certification in the country, gathering all matters related to the halal industry under one umbrella, which is seen as a tremendous effort to better coordinate and unify halal industry practices.

\section{Administration of Islamic Law: State Jurisdictions}

Statistically, Muslims in Malaysia represent 61.3 per cent of the population. ${ }^{12}$ Constitutionally, Islam is the religion of the federation, as stipulated in Article 3 of the Malaysian Federal Constitution. The same Article 3 permits the practice of other religions, with Article 11 of the constitution guaranteeing freedom of religion for the followers of all faiths. Consequently, every Malaysian has the right to practise their religion of choice, subject to the limitations stated in paragraph (4) of Article 11. This paragraph provides that the freedom to propagate any religious doctrines or beliefs among Muslims is limited by State Law in the various states of Malaysia, and under the federal law in the case of the federal territories of Kuala Lumpur, Labuan and Putrajaya.

At present, since halal matters are within the purview of trade, they fall under the jurisdiction of the Ministry of Domestic Trade, Cooperatives and Consumerism - except for halal certification, for which authority is vested in JAKIM and the IRCs (or Majlis Agama Islam Negeri, MAIN) of the various states. This position marked a significant feature of the Trade Descriptions Act (TDA) 2011, which came into force on 18 August $2011,{ }^{13}$ but may have left the nation with the impression that halal matters are the responsibility of the states, as prescribed in Item I of List II of the Ninth Schedule of the Malaysian Federal Constitution. To understand this issue more fully, however, it is pertinent to note the historical development of JAKIM and halal matters in the country.

\section{The Relationship between JAKIM and the Halal Industry: Pre- and Post-Enactment of the Trade Description Act 2011}

The establishment of the National Council of Islamic Religious Affairs in 1968 was consented to by the Conference of Rulers in order to streamline the administration of Islamic affairs in the country. ${ }^{14}$ All states in Malaysia, except for Pahang and Kedah, have become members of the National Council of Islamic Religious Affairs. The secretariat of this Council was entrusted to 
JAKIM, formerly known as Pusat Islam (Islamic Centre). In 1974, the Islamic Centre was upgraded to become a division of the Prime Minister's Department, known as Bahagian Hal Ehwal Islam (BAHEIS): Eventually, in January 1997, the Malaysian cabinet restructured and upgraded BAHEIS as Jabatan Kemajuan Islam Malaysia (JAKIM) ${ }^{15}$ which fell under the care of the Prime Minister's Department.

As far as the halal industry is concerned, JAKIM and the IRCs were made the only authorities for halal certification by two orders, ${ }^{16}$ issued according to Sections 28 and 29 of the Trade Descriptions Act (TDA) 2011. Under the old regulatory regime, namely the Trade Descriptions Act 1972 and its two subsidiary laws, the Trade Descriptions (Use of Expression Halal) Order 1975 and Trade Descriptions (Marking of Foods) Order 1975, JAKIM and the IRCs were not legally recognised as competent authorities for halal certification, even though they were known to be dealing with the matter. Also, the Trade Descriptions (Use of "Halal") Order 1975 allowed individuals or private companies to issue their own certificates and halal logos because the order did not exclusively empower JAKIM or the IRCs to do such. ${ }^{17}$ Consequently, JAKIM and the IRCs were not able to deal with any complaints about the abuse of halal logos or halal certificates, unless the Ministry of Trade was first notified and any action carried out in the presence of ministry officers. ${ }^{18}$ In a nutshell, TDA 2011 elevated the role and status of both JAKIM and the IRCs, making them the only competent authorities for the halal certification process, thereby allowing standardised practice in terms of halal certification. This situation has also implied that halal is a national agenda.

\section{The Halal Certification Process: Cooperation between JAKIM and Other Entities}

Upon receiving an application for halal certification, JAKIM will handle the process according to its Halal Procedure Manual (Halal Manual) and the Halal Assurance System 2011 (HAS 2011). ${ }^{19}$ The halal certification must mandatorily comply with this Halal Manual, in addition to any other rules and regulations, standards issued by DOSM and any state fatwas. Apart from the Halal Manual, JAKIM has also issued other guidelines and circulars from time to time.

The Standards of Malaysia Act 1996 grants extensive power to DOSM to issue standards, including halal-related ones. Currently, sixteen standards have been issued by this body, covering a broad spectrum of halal industries in the country, including food and slaughtering, tourism and hospitality, logistics and handling processes, management and management systems, pharmaceuticals, 
packaging, and cosmetics and personal care products. Compliance with any standards issued by DOSM is voluntary; it is not mandatory unless there is a law to say so. As far as the halal certification process is concerned, compliance with specific standards related to halal is specified in the Halal Manual and HAS 2011.

Apart from DOSM, the law authorises several ministries and agencies to carry out specific procedures for halal certification. The Ministry of Health, for instance, is mandated to carry out and supervise the certification processes relating to Good Manufacturing Practices (GMP) and Hazard Analysis \& Critical Control Points (HACCP), while the Department of Veterinary Services (DVS) of the Ministry of Agriculture is empowered to deal with the meat and livestock industry.

Overall, the halal industry in Malaysia is governed by various bodies mandated under different laws and job scopes. In addition to the TDA 2011 and its by-laws, other laws and regulations governing halal matters include the Food Act 1983, Food Regulations 1985, Consumer Protection Act 1999, Food Irradiation Regulations 2011, Road Transport Act 1987, Customs Act 1967, Customs Order (Prohibition of Imports) 1988, Wild Life Protection Act 1972, Animal (Importation Order) 1962, and a myriad of other guidelines and manuals issued by relevant authorities. ${ }^{20}$

\section{The Road towards Centralised Coordination and Supervision}

The proposed establishment of Majlis Halal Malaysia (MHM, or the Malaysia Halal Council), announced by former Deputy Prime Minister, Ahmad Zahid Hamidi on 11 February 2016, marked a significant milestone towards streamlining the halal industry in Malaysia under centralised supervision. Although this initiative has yet to be enforced - a statute governing its activities will be prepared by MITI and JAKIM, scrutinised by the Attorney General Chambers, and subsequently tabled in Parliament ${ }^{21}$ - it will empower JAKIM to focus on matters related to halal certification, governance and other shariah matters, while HDC will be tasked with developing the industry and its internationalisation strategies. Other agencies or entities that are currently working closely with these two bodies will continue to make their contributions to the industry, as previously mandated.

These efforts are continuously being pursued by the new government, which has announced its commitment to table a new bill known as the 'National Halal Council Bill'. This announcement indicates the government's commitment to centralising halal matters under the federal government. Thus, it is pertinent 
to analyse whether or not the proposed centralisation would trigger any jurisdictional issues.

\section{Legal and Regulatory Outlooks: Federal v States Jurisdictions}

The term 'halal' implies a matter that falls within the ambit of shariah. Notably, therefore, Article 74 of the Malaysian Federal Constitution stipulates a clear division between the powers of the federal and states' governments with respect to shariah. Essentially, the power to administer Islamic law is vested in the states, as stipulated in Item I of List II of the Malaysian Federal Constitution. The said Item I provides that states are vested with control of all Islamic law pertaining to the personal and family circumstances of Muslims, such as succession (either testate or intestate), betrothal, marriage, divorce, dower, maintenance, adoption, legitimacy, guardianship, hibah (gifts), wakafs and other Islamic religious and charitable endowments, trusts and charities (like zakat, fitrah and baitulmal), and punishments for offences committed by Muslims against the precepts of Islam (except in regards to matters included in the Federal List). However, this jurisdiction does not cover the administration of Islamic law for the Federal territories of Kuala Lumpur, Labuan and Putrajaya, which fall within the power of the federal government. ${ }^{22}$

Nonetheless, one may argue that the halal industry does not necessarily fall within a state's jurisdiction. Rather, this matter arguably falls within the purview of Item 8 of List I (Federal List) of the Ninth Schedule, covering matters related to trade, commerce and industry, including (but not limited to) the production, supply and distribution of goods; price control and food control; adulteration of foodstuffs and other goods; imports and exports; incorporation, regulation and winding up of corporations (except municipal corporations), both domestic and foreign; bounties on production in or export from the country; insurance; patents; copyrights; trademarks; establishment of standards of weights and measures and quality for goods manufactured in or exported from the country; auctions; industries and regulation of industrial undertakings; mining, oil and petroleum matters (subject to Item 2(c) in the State List) and also factories. ${ }^{23}$

Moreover, the halal industry is composed of various players, including Muslims, non-Muslims and incorporations. In reality, non-Muslims represent almost 70 per cent of halal market players in Malaysia. ${ }^{24}$ Therefore, placing halal matters within the states' jurisdiction is rendered questionable, since the application of Islamic law as envisaged in Item I of List II of the Ninth Schedule is limited to Muslims only. Furthermore, Item I of List II of the Ninth Schedule 
resembles the intention of the Federal Constitution to limit the application of Islamic law to the personal and domestic affairs of Muslims only, despite the position granted to it as the religion of the Federation as accorded in Article 3 of the Federal Constitution. The reason behind this limitation is to maintain the stat us of the country as secular. The Reid Commission Report 1957 clearly recorded this intention in Item 11:

It has been recommended by the Alliance that the Constitution should contain a provision declaring Islam to be the religion of the State. It was also recommended that it should be made clear in that provision that a declaration to the above effect will not impose any disability on non-Muslim citizens in professing, propagating and practising their religions, and will not prevent the State from being a secular State.

A similar intention was reiterated in Item 169 of the same report, which stated:

We have considered the question whether there should be any statement in the Constitution to the effect that Islam should be the State religion. There was universal agreement that if any such provision were inserted it must be made clear that it would not in any way affect the civil rights of non-Muslims. In the memorandum submitted by the Alliance it was stated the religion of Malaysia shall be Islam. The observance of this principle shall not impose any disability on non-Muslim nationals professing and practising their own religions and shall not imply that the State is not a secular State.

This cardinal principle was clearly maintained in the decision of Supreme Court (now Federal Court) Judge, Tun Saleh Abbas, in the case of Che Omar bin Che Soh v Public Prosecutor [1988] 2 MLJ 55. It was held that:

By ascribing sovereignty to the ruler, i.e. to a human, the divine source of legal validity is severed and thus the British turned the system into a secular institution. Thus all laws including administration of Islamic laws had to receive this validity through a secular fiat...the law in this country is still what it is today, secular law, where morality not accepted by the law is not enjoying the stat us of law.

Thus, halal matters should be placed under the care of the Federal Government on at least two important accounts, namely: 
1. They fall within the meaning of trade, commerce and industry as listed in Item 8 of List I of the Ninth Schedule of the Malaysian Federal Constitution;

2. Halal industry players include non-Muslims and incorporations. Item I of List II of the same schedule does not cover non-Muslims or incorporations as far as the administration of Islamic law in the states is concerned.

Concerning the first point, placing halal under the purview of trade, commerce and industry could put it on a similar path to Islamic banking and finance. The law governing Islamic banking and finance is civil law, with the court for adjudication of Islamic financial disputes being the civil court, not the shariah court.

In the case of Bank Kerjasama Rakyat Malaysia Bhd v. Emcee Corporation Sdn Bhd [2003] 1 CLJ 625, the court decided that Islamic banking and finance falls under the jurisdiction of the federal government as listed in Items 7 and 8 of List I of the Ninth Schedule. Although Islamic banking and finance carries the word 'Islamic', the nature of the business activities involved places it within the boundaries of banking, commerce, trading and insurance, as governed by the federal government. This situation is analogous to the halal industry; although the term 'halal' carries Islamic connotations, the nature of the activities and transactions involved falls within the ambit of trade, commerce and industry, which in turn falls within the jurisdiction of the federal government.

Likewise, in the case of Low Chin Meng v. CIMB Islamic Bank Bhd [2015] $5 C L J 324$, hibah was utilised as one of the supporting contracts for the Islamic facility granted by the bank to the customer. Although hibah falls within the jurisdiction of the states, in this case, when hibah was tied to an Islamic banking facility, it fell under the jurisdiction of the federal government.

\section{Conclusion and Recommendations}

One of the factors hindering the growth of halal trade worldwide is nonuniformity of halal standards. Thus, a set of global halal standards is a must in order to accelerate the promising growth of halal trade activities. Efforts towards unifying and standardising halal trading practices has already begun under the auspices of members of the Standards and Metrology Institute for Islamic Countries (SMIIC), who have been developing international halal standards on a gradual basis. Malaysia is a participating member of this endeavour. At the domestic level, this objective could be facilitated by having a 
centralised regulatory and governmental body for halal matters. This aim could be actualised in Malaysia; an analysis of its legal provisions and cases reveals that halal matters are within the jurisdiction of the federal government.

This study suggests the following recommendations:

- Constitutionally, halal matters in Malaysia should be centralised under the federal government's jurisdiction, as they fall within the ambit of Item 8 of List I of the Ninth Schedule of the Malaysian Federal Constitution.

- The proposed National Halal Council Bill should fall under the purview of the federal government, just as the Islamic Financial Services Act 2013 does.

- The Malaysian Halal Council (MHC) should become the apex authority for halal supervisory and governance functions. It would be analogous to the Shariah Advisory Council (SAC) governing Islamic financial services.

- Centralised coordination must be effective in order to avoid unnecessary overlap between ministries and halal-related agencies.

- Harmonisation of halal trading practices through a centralised regulatory and supervisory regime could further boost the development of the halal industry, both domestically and globally.

The proposed centralised supervision of the halal industry under the federal government is key to maintaining Malaysia's position as the world's largest global halal hub. In the meantime, improved coordination and supervision will secure Malaysia's competitive edge as leader of the global halal market.

\section{Notes}

* Apnizan Abdullah, Research Fellow, International Institute of Advanced Islamic Studies (IAIS) Malaysia.

** Mohamed Azam Mohamed Adil is Deputy CEO, International Institute of Advanced Islamic Studies (IAIS) Malaysia/Associate Professor, Academy of Contemporary Islamic Studies (ACIS), Universiti Teknologi MARA Selangor, 40450 Shah Alam, Selangor (mazamadil@iais.org.my/mazamadil@hotmail. com).

1. 'Eye on Asia,' Data Spring. Available at: https://www.d8aspring.com/eye-on- 
asia/opportunities-in-the-halal-industry-dataspring-eye-on-asia.

2. 'Global Halal Market statistic \& Facts,' Statista. Available at: https://www. statista.com/topics/4428/global-halal-market/

3. 'Market value of halal foods worldwide from 2017 to 2023 (in trillion U.S. dollars),' Statista. Available at: https://www.statista.com/statistics/562857/ market-value-of-halal-products-worldwide/.

4. 'The Future of the Global Muslim Population,' Pew Research Centre. Available online at: https://www.pewforum.org/2011/01/27/the-future-of-the-globalmuslim-population/.

5. 'State of the Global Islamic Economy Report 2018/19,' DCIE \& Thomson Reuters, 2019. Available at: www.SalaamGateway.com.

6. 'Malaysia Championing the Halal Industry,' MIHAS. Available at: http://mihas. com.my/malaysia-championing-the-halal-industry/.

7. Apnizan Abdullah and Mohammad Hashim Kamali, 'Shariah Parameters for the Halal Industry in Malaysia: Issues \& Reforms,' IAIS Policy Issue Papers no. 5 (2018).

8. The Sunday Daily, 6 March 2019.

9. n. 6 .

10. 'Malaysia to Enter 10 New Halal Markets Via OBOR,' The Star, 22 May 2019. Available at: https://www.thestar.com.my/business/business-news/2019/05/22/ malaysia-to-enter-10-new-halal-markets-via-obor/\#P3Lz4p2hfu0HERtQ.99 https:/www.thestar.com.my/business/business-news/2019/05/22/malaysia-toenter-10-new-halal-markets-via-obor/.

11. Elly Fazaniza, 'New Law in the Works to Streamline Halal Certification,' The Sun Daily, 2 April 2019. Available at: https:/www.thesundaily.my/local/newlaw-in-the-works-to-streamline-halal-certification-HI749180.

12. As of 2014. For further details, refer to: http://www.indexmundi.com/malaysia/ demographics_profile.html (Accessed on: 19 September 2015).

13. The Trade Descriptions (Definition of Halal) Order 2011 and Trade Descriptions (Certification and Marking of Halal) Order 2011 are sub-laws or orders issued by the Minister of Domestic Trade, Cooperatives and Consumerism, as authorised under Sections 28 and 29 of the TDA 2011. These two orders, in addition to TDA 2011, confirm that JAKIM and the IRCs of each state in Malaysia (except the federal territories) are the legitimate bodies for halal certification in Malaysia, bearing a specified halal logo.

14. The Conference of Rulers is constitutionally bestowed by the Federal Constitution with certain privileges vide Article 38. For further details on the creation of the National Council of Islamic Religious Affairs, see Farid Suffian Shuib, 'Strengthening Administrative Institutions of Islamic Law in Malaysia: An Overview,' Jurnal Syariah 16 (2008): 443-64.

15. See for further details see http://www.islam.gov.my/en/about-jakim. (Accessed on: 19 September 2016).

16. n.15.

17. Mustafa 'Afifi Ab. Halim and Azlin Alisa Ahmad, 'Asian Enforcement of Consumer Protection Laws on Halal Products: Malaysian Experience,' Asian Social Science 10, no. 3 (2014): 10.

18. Zalina Zakaria and Siti Zubaidah Ismail, 'The Trade Description Act 2011: 
Regulating Halal in Malaysia,' International Conference on Law, Management and Humanities (ICLMH '14), 21-22 June 2014, Bangkok, Thailand, 9.

19. As of writing, the applicable manual is the Manual Procedure for Malaysia Halal Certification (Third Revision) 2014. This manual is revised by JAKIM from time to time. Paragraph 5 and 6 of 2014's manual state clearly that this revised manual is produced in line with the Malaysia Guidelines on the Halal Assurance System 2011 (HAS 2011) and the amendments made on the definition of SME industry released by the government through SME Corp.

20. n. 7.

21. Refer to: http://www.hmetro.com.my/node/114202. (Accessed on: 28 August, 2016).

22. ILBS, Federal Constitution (Petaling Jaya: ILBS, 2014), 272.

23. n. 24, 267-8.

24. Danisha, 'Non-Muslims Represent almost $70 \%$ of Halal Industry in Malaysia,' The Coverage, 13 June 2017. Available at: https://thecoverage.my/news/nonmuslims-represent-almost-70-halal-industry-malaysia/. 